\title{
Blaski i cienie reformy programowej w edukacji przedszkolnej i wczesnoszkolnej - postawy nauczycieli
}

Według autorów Raportu o Kapitale Intelektualnym Polski z 2008 roku indeks kapitału intelektualnego ${ }^{l}$ dla dzieci i mtodzieży plasuje Polske na 13. miejscu pośród 16 krajów europejskich, które objęte sa porównaniem ${ }^{2}$. Najwyższe wskaźniki w tej analizie mają Niemcy, Węgry i Austria. Poniżej Polski znajdują się: Finlandia, Portugalia i Grecja. Jako powody tej niekorzystnej sytuacji podaje się $\mathrm{m}$. in. niską partycypację 4-latków w edukacji, stosunkowo wysoki wskaźnik umieralności dzieci poniżej 5. roku życia oraz niski procent młodzieży deklarujących zainteresowanie przyszłą pracą związaną z nauką ${ }^{3}$. Stawiając pytanie: Jak podnieśś jakość wczesnej edukacji? autorzy raportu wymieniają następujące przesłanki, przyczyny niezadowalającego poziomu jakości wczesnej edukacji:

- btędne stereotypy dotyczqce edukacji na wczesnym etapie utrudniaja jej rozpowszechnienie,

- rodzice nie sq wtaściwie zaangażowani w proces uczenia dzieci na etapie przedszkolnym, snej ${ }^{4}$.

- niezadowalajacy jest poziom przygotowania nauczycieli edukacji wcze-

Ta ostatnia kwestia interesuje nas najbardziej, ponieważ problem przygotowania nauczycieli, powraca jak bumerang przy okazji debat i dyskusji o postawach nauczycieli, o ich osobowości, rekrutacji do zawodu, o jakości świadczonych przez nich usług edukacyjnych, ale także, a może przede wszystkim

\footnotetext{
${ }^{1}$ Kapitał intelektualny Polski to ogół niematerialnych aktywów ludzi, przedsiębiorstw, społeczności, regionów i instytucji, które odpowiednio wykorzystane mogą być źródłem obecnego i przyszłego dobrostanu kraju (w:) M. Sielatycki, Szkoła jako miejsce tworzenia kapitału ludzkiego i społecznego, „Dyrektor Szkoły” 2010, nr 2, s. 21.

${ }^{2}$ Raport o Kapitale Intelektualnym Polski, Zespół Doradców Strategicznych Prezesa Rady Ministrów, Warszawa 2008, s. 30.

${ }^{3}$ Tamże.

${ }^{4}$ Tamże, s. 41-42.
} 
wtedy, gdy wprowadzane są kolejne zmiany w edukacji. W cytowanym wyżej raporcie czytamy, iż polepszenie jakości instytucji zajmujacych się matymi dziećmi nie jest możliwe bez podniesienia kompetencji kadry nauczycielskiej. Obecnie brakuje odpowiedniej oferty programów rozwijajacych kwalifikacje nauczycieli przedszkolnych $w$ zakresie: pracy grupq różnowiekowa, pracy zdzieckiem trudnym, partnerskiej wspótpracy z rodzicami, obserwacji dzieci, konstruowania indywidualizowanych planów rozwoju oraz dokumentowania rozwoju dzieci ${ }^{5}$.

\section{O przygotowaniu nauczycieli do zmian}

Przygotowanie nauczycieli do nowych zadań i współczesnych wyzwań w edukacji przedszkolnej i wczesnoszkolnej musi obejmować następujące obszary:

a) przygotowanie do zawodu w trakcie studiów - poznawanie i identyfikowanie nowych procesów, zjawisk i kierunków zmian w społeczeństwie i edukacji; umiejętność postawienia diagnozy dziecka, jego poziomu rozwoju i potencjału edukacyjnego; znajomość i wykorzystanie sposobów myślenia i działania w sytuacjach trudnych, konfliktowych; umiejętność krytycznej oceny i wyboru programu kształcenia i wychowania, lub bardziej nowatorskie - tworzenie własnych, autorskich programów edukacyjnych;

b) doskonalenie i dokształcanie nauczycieli w trakcie pracy zawodowej elastyczne reagowanie na potrzeby społeczne i edukacyjne, ale także kreowanie potrzeb w zakresie samorealizacji zawodowej nauczyciela (np. zmiana specjalności); skuteczne ograniczanie rutyny i objawów wypalenia zawodowego poprzez zmianę nastawienia i mentalności nauczycieli wobec współczesnych problemów w kształceniu i wychowaniu; uświadamianie i eliminowanie „pozoranctwa edukacyjnego" i wygodnictwa nauczycieli (np. nagminne korzystanie z tzw. kart pracy i różnego typu ,kserówek”, wypełnianie ćwiczeń przez dzieci itd.);

c) przygotowanie nauczycieli do zmian edukacyjnych - systematyczne i profesjonalne dostarczanie jak największej ilości rzetelnych i konkretnych informacji o wprowadzanych zmianach; dzielenie się z nauczycielami - praktykami wiedzą i refleksjami na temat zmian przez pracowników naukowych uczelni pedagogicznych (np. z wizyt studyjnych i staży naukowych); przekazywanie doświadczeń i upowszechnianie dobrych praktyk przez szkoły przodujacce, innowacyjne, pilotażowe w kwestii popularyzacji zmian; praktyczna ewaluacja wprowadzanych zmian: programów edukacyjnych, zaleceń dydaktycznych w zakresie metod i form realizacyjnych, planów nauczania, proponowanych zajęć edukacyjnych itd.

\footnotetext{
${ }^{5}$ Tamże.
} 
W ciągu ostatnich dziesięcioleci uległ zmianie wizerunek roli nauczyciela, szczególnie zaś obraz nauczyciela wczesnej edukacji, w więc osoby zajmującej się dziećmi w wieku 3-10 lat. Tradycyjne spojrzenie na nauczyciela - jako na kogoś, kto przekazuje dzieciom wiedzę i umiejętności, pośrednika między dzieckiem a programem nauczania - jest kwestionowane. Natomiast coraz częściej podkreśla się, że podstawowym zadaniem nauczyciela jest wspieranie rozwoju dziecka, planowanie i konstruowanie indywidualnych programów rozwojowych dla każdego z nich. Rola nauczyciela nie jest więc postrzegana w kategoriach instruktora, ale obserwatora, śledzącego i diagnozującego poszczególne etapy rozwoju dziecka, planującego i organizującego odpowiednie, dostosowane do indywidualnych potrzeb działania edukacyjne, mediatora i partnera dbającego o optymalny rozwój uczniów. Ta zmiana wizerunku roli nauczyciela wpływa też na określenie celów i zadań w procesie kształcenia nauczycieli ${ }^{6}$. Amerykańscy badacze Bernard Spodek i Olivia N. Saracho wyodrębnili cztery obszary wiedzy, umiejętności i wartości niezbędnych do pełnienia funkcji nauczyciela małych dzieci:

- psychologiczna wiedza o rozwoju dziecka oraz teoriach pedagogicznych organizujących proces edukacyjny,

- wiedza o konstruowaniu programu ułatwiającego wspieranie indywidualnego rozwoju dziecka,

- wiedza o metodach tworzenia bezpiecznego i stymulującego uczenie się środowiska edukacyjnego,

- wiedza o monitorowaniu rozwoju dziecka i ewaluacji (oceny) efektów pracy nauczyciela.

Nauczyciel w toku kształcenia powinien zdobyć umiejętności pozwalające na wnikliwe obserwacje, na analizę środowiska edukacyjnego, ale także umożliwiające efektywną pracę $\mathrm{w}$ zespole, współpracę $\mathrm{z}$ kolegami i partnerami. Istotne jest również rozwinięcie poczucia świadomości i odpowiedzialności za proces edukacji ${ }^{7}$.

O tym, że musi ulec zmianie podejście do kształcenia i doskonalenia nauczycieli wczesnej edukacji (i nie tylko wczesnej) w Polsce przekonują się już środowiska samych nauczycieli, jak środowiska akademickie i instytucje doskonalenia zawodowego, które opracowują coraz nowocześniejsze programy i oferty kształcenia. Zmianę wywołują również bezwzględne reguły rynku pracy w sferze edukacji, kształtujące popyt na określony typ wykształcenia, kierunek i specjalność oraz polityka unijna. Pisze o tym Stig G. Lund w swoim artykule „Edukacja zawodowa nauczycieli”: Programy wczesnej opieki i edukacji $i^{8}$ należa

${ }^{6}$ M. Żytko, Kształcenie i doskonalenie nauczycieli, [w:] T. Szlendak (red.), Małe dziecko w Polsce. Raport o sytuacji edukacji elementarnej, Warszawa 2006, s. 90.

${ }^{7}$ Tamże.

${ }^{8} \mathrm{~W}$ terminologii używanej w dokumentach i opracowaniach unijnych wczesna edukacja i opieka nad dzieckiem oznacza edukację przedszkolną. Por. Wczesna edukacja i opieka nad 
do priorytetowych zadań Unii Europejskiej, ponieważ umożliwiaja stałe podnoszenie kwalifikacji, realizacje Strategii Lizbońskiej na rzecz rozwoju, zatrudnienia $i$ edukacji oraz ułatwiaja pogodzenie życia rodzinnego $i$ zawodowego. Jednocześnie traktaty europejskie nie daja wtadzom unijnym wystarczajacych uprawnień, by ingerować $w$ oświate państw członkowskich - zezwalaja jedynie na wymianę doświadczeń, dzielenie się wiedzq i prowadzenie innych podobnych inicjatyw spotecznych. Niemniej, Unia - czyli Rada, Komisja i Parlament podejmuje czynne działania, zwłaszcza $w$ dziedzinie edukacji wczesnodziecięcej, co wiaże się z kwestia wyksztatcenia kadry pedagogicznej. [...] Unia zachęca państwa członkowskie do inwestowania $w$ wychowanie przedszkolne, a także by zwiększyty liczbe specjalnie wyszkolonych nauczycieli $i$ stwierdza, że edukacja przedszkolna i pedagogika stosowana wobec najmłodszych powinny skupiać się $w$ równej mierze na nabywaniu wiedzy, jak i na rozwijaniu kompetencji osobistych $i$ społecznych ${ }^{9}$.

Natomiast, jeśli chodzi o przygotowanie nauczycieli do zmian i reform, zmienia się niewiele. Z badań przeprowadzonych w 1999 roku ${ }^{10}$ wśród nauczycieli szkół w czterech powiatach województwa mazowieckiego wynikało, że nauczyciele nie znali dobrze założeń ówczesnej reformy systemu edukacji, bardzo krytycznie odnosili się do strategii realizacji reformy, mieli duże wątpliwości co do zakresu i tempa wprowadzanych zmian, sprzeciw budził również organizacyjny i finansowy aspekt reformy. Generalnie jednak popierali potrzebę reformowania edukacji i wprowadzania zmian, nie czując się ich aktywnymi uczestnikami. Nie byli też zbyt zainteresowani zmianami, a ciekawym spostrzeżeniem był fakt, że nauczyciele wykazali się w większości słabą znajomością zmian w programach nauczania, oceniając je jednocześnie najbardziej pozytywnie. $\mathrm{W}$ innych badaniach ${ }^{11}$ wyraźną niechęć pod adresem reformy wyrażało około $20 \%$ nauczycieli, a większość miała ambiwalentne poglądy na ten temat. [...] Część wolałaby żeby reformy w tak szerokim zakresie nie było, a w każdym razie by została odłożona. Już wtedy ostrzegano przed tzw. pozornym przyzwoleniem na reformę. Nauczyciele dostosują się do zmian, bo nie będą mieli innego wyboru, jednak w wyborach programów i metod pracy będą kierować się dotychczasowymi przyzwyczajeniami.

W wielu badaniach dowiedziono już, że prawdziwa jest opinia Bogusława Śliwerskiego, iż kluczowym czynnikiem funkcjonowania systemu edukacji

dzieckiem w Europie: zmniejszanie nierówności społecznych $i$ kulturowych, Fundacja Rozwoju Systemu Edukacji, Warszawa 2009.

${ }^{9}$ S. G. Lund, Edukacja zawodowa nauczycieli, Fundacja Rozwoju Dzieci im. J. A. Komeńskiego, ,Dzieci w Europie” 2009, nr 15, s. 6.

${ }^{10}$ Por. M. Kamińska-Juckiewicz, Postawy i zachowania nauczycieli wobec reformy edukacji w Polsce, Płock 2002, s. 243.

${ }^{11}$ E. Putkiewicz, K. Sielawa-Kolbowska, A. Wiłkomirska, M. Zahorska, Nauczyciele wobec reformy edukacji. Raport z badań, Warszawa 1999, s. 156. 
$i$ wprowadzania $\mathrm{w}$ nim reform jest odpowiednio przygotowana i umotywowana kadra pedagogiczna. Niestety, po PRL odziedziczyliśmy niedowartościowanie ekonomiczne nauczycieli, niskie poczucie wartości spotecznej wykonywanego zawodu, spadek zainteresowania pracq $i$ zaangażowania $w$ nia, prowadzqce do negatywnej selekcji do zawodu, do ostabienia etosu pracy, do poczucia bezsensu czy do wyuczonej bezradności. Zmiana ustrojowa w niewielkim stopniu poprawita sytuacje tej grupy zawodowej, najbardziej świadomej potrzeb zmian, a przy tym sukcesywnie podnoszqcej swoje kwalifikacje i uzyskujacej wyższe wyksztatcenie $^{12}$. Odgórny, urzędniczy tryb wprowadzania przez MEN innowacji czy reform oświatowych wpływa na to, że nauczyciele czują się niewolnikami systemu, choć całkiem innego. Reagują zatem oporem, w myśl reguły: „wiedzieć swoje”, nie przyjmować ministerialnych argumentów i „robić swoje” lub protestować. Nauczyciele reagują na kolejne propozycje reform w stary, wyuczony sposób i, choć może akceptują hasła czy etykiety, ich schematy interpretatywne pozostają bez zmian. Reformatorzy z centrali traktowani są jak „handlarze metaforami”, pod których powierzchnią kryje się twarda, stara rzeczywistość ${ }^{13}$.

\section{O upowszechnianiu zmian}

Zgodnie z deklaracjami reformatorów, głównymi celami aktualnych zmian w oświacie, wprowadzanych pod hasłem Szkoła skuteczna, przyjazna i nowoczesna jest:

1. wzmocnienie pozycji zawodowej nauczyciela;

2. upowszechnienie wychowania przedszkolnego dla dzieci w wieku 3-5 lat, w tym obowiązek rocznego przygotowania przedszkolnego dla dzieci 5-letnich;

3. zapewnienie lepszego dostępu do edukacji najmłodszych dzieci przez obniżenie wieku rozpoczynania obowiązku szkolnego do wieku 6 lat, co umożliwi wykorzystanie potencjału systemu szkolnego dla wyrównywania szans oraz wczesnego odkrywania uzdolnień;

4. reforma programowa wychowania przedszkolnego i kształcenia ogólnego ukierunkowana na precyzyjny opis efektów kształcenia na każdym etapie edukacyjnym oraz zwiększenie autonomii szkół w kreowaniu procesu kształcenia;

5. poprawa jakości kształcenia zawodowego, zaspokajania specjalnych potrzeb edukacyjnych oraz warunków uczenia się przez całe życie;

${ }^{12}$ B. Śliwerski, Problemy wspótczesnej edukacji. Dekonstrukcja polityki oświatowej III RP, Warszawa 2009, s. 41.

${ }^{13}$ Tamże, s. 33. 
6. otwarcie polskiego systemu edukacji na świat, działania na rzecz integracji cudzoziemców w polskim systemie oświaty i wspieranie nauczania polskich dzieci poza granicami Polski;

7. poprawa jakości edukacji przez odbiurokratyzowanie nadzoru pedagogicznego i jasny rozdział zadań między organy prowadzące szkoły oraz organy sprawujące nadzór pedagogiczny, będący elementem racjonalnej decentralizacji części kompetencji państwa w obszarze oświaty i wychowania ${ }^{14}$.

Sporo miejsca w początkowej fazie realizacji reformy poświęcono edukacji przedszkolnej i wczesnoszkolnej, skupiając się na przedsięwzięciach strukturalnych i programowych. Zaplanowano również szereg posunięć finansowych związanych z nauczycielskimi płacami, ale światowy kryzys gospodarczy uniemożliwił, jak na razie, realność tych propozycji. Dziś (kwiecień 2010) mamy już za sobą wrześniowy debiut nowej podstawy programowej wychowania przedszkolnego (we wszystkich grupach wiekowych w przedszkolu) i edukacji wczesnoszkolnej (w klasie I). Nauczyciele zostali postawieni w nowej sytuacji, mając świadomość niedostatecznej wiedzy na temat praktycznej realizacji treści programowych. Zdążyli również zauważyć, że zapisy dotyczące warunków i sposobów realizacji są w wyraźnej sprzeczności z rzeczywistością szkolną i przedszkolną. Pomimo szeregu działań podjętych przez MEN, aby upowszechnić zmiany, zainteresowanie okazało się znikome. Edyta Gruszczyk Kolczyńska jako współautorka nowej podstawy programowej edukacji przedszkolnej i wczesnoszkolnej w materiałach edukacyjnych dotyczących rozwiązań metodycznych ${ }^{15}$, przedstawiła swoje propozycje wdrożeniowe dla nauczycieli. Materiał został opublikowany w październiku 2009 roku. Czytamy w nim, że: Od poczatku roku szkolnego 2009/2010 edukacja przedszkolaków i uczniów klasy I szkoły podstawowej prowadzona jest zgodnie z wytycznymi zawartymi w nowych Podstawach programowych wychowania przedszkolnego i Podstawach programowych edukacji wczesnoszkolnej. Dokumenty te zostaty skonstruowane na zasadzie stopniowych przyblizeń: kolejne wersje wielokrotnie poprawiano, uwzględniajac uwagi $i$ propozycje zebrane $w$ ramach konsultacji społecznych oraz recenzje specjalistów wychowania przedszkolnego $i$ edukacji wczesnoszkolnej. Po tych korektach nadano im formę dokumentów załaczonych do Rozporzqdzenia Ministra Edukacji Narodowej z dnia 23 grudnia 2008 r. W styczniu 2009 r. Podstawy programowe wychowania przedszkolnego i Podstawy programowe edukacji wczesnoszkolnej zostaty podane do powszechnej wiadomości w Dzienniku Urzędowym (nr 4 z 15 stycznia 2009 r.) oraz na

${ }^{14}$ Informacja rzqdu na temat aktualnej sytuacji i działań podejmowanych $w$ polskiej oświacie. Edukacja skuteczna, przyjazna i nowoczesna, MEN, Warszawa 2008, s.7.

${ }^{15} \mathrm{http} / / / \mathrm{www}$. bc.ore.edu.pl/dlibra/docmetadata?id=132\&from=pubindex\&dirids=10, E. Gruszczyk-Kolczyńska, Edukacja przedszkolna $i$ wczesnoszkolna- nowe podstawy programowe. Konferencje szkoleniowe, poświęcone szczegótowej analizie celów, treści i warunków ksztatcenia dzieci we wszystkich obszarach edukacyjnych, październik 2009. 
stronach internetowych Ministerstwa Edukacji Narodowej. W czerwcu 2009 r. wszystkie placówki oświatowe otrzymaty ośmiotomowa publikacje poświęcona nowej podstawie programowej. Tom pierwszy tej serii dotyczy edukacji przedszkolnej $i$ wczesnoszkolnej i zawiera:

- informacje o potrzebie reformy programowej ksztatcenia ogólnego,

- Podstawe programowa wychowania przedszkolnego, zalecane warunki i sposób realizacji, a także komentarz do podstawy programowej wychowania przedszkolnego,

- Podstawe programowa edukacji wczesnoszkolnej, zalecane warunki i sposób realizacji oraz komentarz do podstawy programowej edukacji wczesnoszkolnej,

- opinie Rady Gtównej Szkolnictwa Wyższego i Rektorów Akademickich Szkót Polskich o podstawie programowej ${ }^{16}$.

W materiale jest mowa także o dostępności do dokumentów reformy dla „osób zainteresowanych edukacją przedszkolną i wczesnoszkolną” oraz o „licznych konferencjach i zebraniach rad pedagogicznych", na których nauczyciele mieli możliwość zapoznania się z nową podstawą. Fakt, że nauczyciele uczestniczyli w takich konferencjach i spotkaniach nie świadczy jednak o tym, iż doskonale orientują się $\mathrm{w}$ treściach programowych. A zalecenie o konieczności jednoczesnego zapoznania się z podstawą obowiązującą w następnych etapach edukacyjnych jest już zupełną abstrakcją. W swoim materiale E. Gruszczyk Kolczyńska jednak dość racjonalnie ocenia sytuację: $Z$ rozmów z nauczycielami wynika jednak, że spetnienie tych wymogów jest trudne, gdyż nie dysponujq oni należyta wiedza pedagogicznq dotyczqca realizacji treści ksztatcenia $w$ wielu obszarach edukacyjnych zawartych w nowych Podstawach. Dotyczy to zarówno ksztattowania konkretnych wiadomości $i$ umiejętności, jak $i$ wspomagania rozwoju umystowego dzieci, budowania systemu wartości, a także wielu innych ważnych zakresów kształtowania dziecięcych umystów. Problem polega na tym, ze istniejace metodyki wychowania przedszkolnego i edukacji wczesnoszkolnej w wielu zakresach nie uwzględniaja tego, co zawieraja nowe Podstawy. Nim zostanq opracowane takie metodyki, trzeba pilnie organizować konferencje szkoleniowe, w ramach których omówi się szczegótowo treści ksztatcenia oraz ich realizacje wedtug zalecen zawartych w Podstawach programowych edukacji przedszkolnej $i w$ Podstawach programowych edukacji wczesnoszkolnej. Niezbędne jest także omówienie uwarunkowań psychologicznych oraz ustalen metodycznych. Chodzi przecież o to, aby nauczyciele potrafili organizowac i prowadzić edukacje przedszkolna $i$ wczesnoszkolnq $w$ sposób przyjazny dla rozwoju umystowego dzieci $i^{17}$.

\footnotetext{
${ }^{16}$ Tamże, s. 2.

${ }^{17}$ Tamże, s.3.
} 


\section{Stosunek nauczycieli do zmian a ich kompetencje}

Nauczyciele rzeczywiście są zagubieni i niepewni w kwestii praktycznych rozwiązań i działań wdrożeniowych. Na konferencji metodycznej pod hasłem „Szkoła dla sześciolatka”, którą zorganizowała z własnej inicjatywy jedna z płockich szkół podstawowych w marcu 2010 roku $^{18}$, w czasie dyskusji nauczyciele edukacji wczesnoszkolnej wymieniali się doświadczeniami i refleksjami o reformie programowej. Mieli wyraźne negatywne zdanie na temat pozostawienia ich bez realnej pomocy, braku zaplecza sprzętowego w szkołach związanego $\mathrm{z}$ obniżeniem wieku obowiązku szkolnego, braku funduszy na wyposażenie klas (komputery, meble, zabawki). Zwracano uwagę na niespójność nowych treści programowych $\mathrm{z}$ aktualnym przygotowaniem dzieci, rozpoczynających naukę $\mathrm{w}$ klasie I. Obawy i wątpliwości budzi także brak zapisów w nowej podstawie, dotyczących wymagań edukacyjnych w klasie II, trzeba przecież na koniec roku ustalić kryteria oceny opisowej dla tych uczniów. Niemałym problemem jest również niezadowolenie rodziców dzieci w klasach I, ponieważ obecny program nauczania je ,uwstecznia” w stosunku do tego, co poznawały w przedszkolu. Nasuwa się refleksja, jak ten obraz przystaje do niezbyt odkrywczego stwierdzenia reformatorów: Nowocześnie wykształcony nauczyciel edukacji przedszkolnej $i$ wczesnoszkolnej umie zorganizować prace matych dzieci i otoczyć je opiekq. Wie, że wymagaja one częstych zmian form działania, często indywidualnego podejścia, różnicowania wymagań, doceniania choćby najmniejszych osiagnięć. Wie, że muszq nauczyć się samodzielności, wspótpracy, potrafi przeplatać naukę aktywnymi ćwiczeniami i rekreacja, uczyć przez grę i zabawę. Wplatać w czas pracy ucznia specjalnie dla niego zaprojektowane zajęcia $i$ zadania wyrównująe deficyty czy rozwijająe szczególne talenty. Dla dobrze przygotowanego nauczyciela to jest oczywiste $i$ stanowi staty element jego warsztatu pracy ${ }^{19}$. Jestem głęboko przekonana, że nauczyciele doskonale o tym wiedzą, a podstawowym problemem nie jest wiedza i umiejętności, ale zmiana sposobu patrzenia na dziecko $\mathrm{w}$ szkole $\mathrm{i} \mathrm{w}$ przedszkolu, zmiana mentalności, przełamanie biernej postawy i niechęci wobec innego działania pedagogicznego. Myślenie życzeniowe i dyrektywność posunięć władz oświatowych, niestety, temu nie służą. Jak zwykle mamy do czynienia ze swoistym ,zaklinaniem rzeczywistości” ze strony MEN. Jasną sprawą jest potrzeba nowoczesnego i skutecznego, a zarazem przyjaznego organizowania edukacji przedszkolnej i wczesnoszkolnej. Nie ma wątpliwości, że treści

${ }^{18}$ www.sp22.pl

${ }^{19}$ Informacja rzqdu na temat aktualnej sytuacji $i$ dziatań podejmowanych $w$ polskiej oświacie. Edukacja skuteczna, przyjazna i nowoczesna, Ministerstwo Edukacji Narodowej, Warszawa 2008, s. 4. 
kształcenia powinny podlegać ewaluacji i zabiegom dostosowawczym do wymagań społeczeństwa wiedzy. Na równi jednak powinniśmy stawiać kwestię skutecznego i nowoczesnego przygotowania merytorycznego i przyjaznego nastawienia kadry nauczycielskiej.

Podobne opinie pojawiały się już wcześniej, kiedy kilka lat temu przygotowywano wstępny projekt Podstawy programowej edukacji elementarnej. Mówiono i pisano o trudnościach, jakie napotykaja w swojej pracy nauczyciele oraz ci, którzy chca i powinni ich do tej pracy przygotowywać. W tych poszukiwaniach skutecznych dziatań jest próba zmiany sposobu myślenia i postaw szczególnie nauczycieli wychowania przedszkolnego i ksztatcenia zintegrowanego. W edukacji należy zachować równowagę między możliwościami, dażeniami dziecka a stawianymi mu wymaganiami. Nauczyciel powinien starać się tak modyfikować swoje zachowanie, aby stawato się instrumentem rozwoju, to znaczy umożliwiało każdemu dziecku, uczniowi odkrycie swojego miejsca na świecie $i$ zwiększato szanse na dalszy rozwój ${ }^{20}$.

Dzięki zmianom ustawowym ${ }^{21}$ edukacja przedszkolna może być dziś prowadzona w różnych formach, nie tylko tradycyjnych przedszkolach, oddziałach przedszkolnych $\mathrm{w}$ szkołach, ale również $\mathrm{w}$ formach alternatywnych: w zespołach wychowania przedszkolnego - zajęcia są prowadzone w niektóre dni tygodnia lub w punktach przedszkolnych - zajęcia są prowadzone codziennie. Nowe rozwiązania organizacyjne przewidują również rozszerzenie funkcji tradycyjnego przedszkola do roli bazy dla gminnego centrum edukacji i wspierania rozwoju małego dziecka. Istniejące przedszkola, wraz z zespołami wychowania przedszkolnego, będą też punktami przedszkolnymi, mogą tworzyć sieć i stanowić lokalne centrum, pełniące wielorakie funkcje edukacyjne, kulturalne, integracji i pomocy środowiskowej na rzecz wspierania rozwoju małego dziecka i jego rodziny. Wymaga to od nauczycieli przedszkola dodatkowych umiejętności, o których pisze Edyta Gruszczyk-Kolczyńska ${ }^{22}$. Jej zdaniem, nauczyciele wychowania przedszkolnego muszą bowiem umieć:

1) organizować wychowanie przedszkolne stosownie do potrzeb lokalnych społeczności, jednak z zachowaniem standardów obowiązujących w pedagogice przedszkolnej. w procesie wspomagania rozwoju psychoruchowego dzieci i zapewnienia im większych szans edukacyjnych [...];

${ }^{20}$ E. Brańska, Edukacja elementarna w perspektywie zmian ustawowych, [w:] S. Guz (red.), Rozwój i edukacja dziecka. Szanse i zagrożenia, Lublin 2005, s. 108.

${ }^{21}$ Jak organizować edukacje przedszkolnq $w$ nowych formach. Informator, Ministerstwo Edukacji Narodowej, Warszawa 2008, s. 14.

${ }^{22}$ E. Gruszczyk-Kolczyńska, O blaskach i cieniach zawodu nauczyciela przedszkola. Także o tym, co zniszczyty decyzje polityczne lat dziewięćdziesiatych z dorobku 170 lat wychowania przedszkolnego w Polsce, [w:] H. Moroz (red.), Problemy doskonalenia systemu edukacyjnego w Polsce, Kraków 2008, s. 259. 
2) prowadzić zajęcia $w$ grupach złożonych dzieci od 2. do 6. roku, z uwzględnieniem ich zróżnicowanych potrzeb rozwojowych i różnej podatności na oddziaływania wychowawcze i edukacyjne [...];

3) prowadzić zajęcia w przedszkolnych grupach integracyjnych [...];

4) współpracować z rodzicami i negocjować z władzami lokalnymi (marketing edukacyjny) w sprawie warunków i metod bezpiecznego organizowania wychowania przedszkolnego i zapewnienia dzieciom lepszych szans edukacyjnych $[\ldots]$.

Warunkiem koniecznym do spełnienia, gdy mówimy o zmianach edukacji przedszkolnej i wczesnoszkolnej są niewatpliwie postawy i kompetencje nauczycieli. Stosunek nauczycieli do założeń i procesu realizacji zmian decyduje zazwyczaj, jak są one odbierane i oceniane przez pozostałych uczestników edukacji: rodziców i ich dzieci. Decyduje o efektywności zmian wprowadzanych w życie. Mając to na uwadze, można wyznaczyć obszar badawczy o charakterze pedeutologicznym, obejmujący szerokie spektrum zjawisk, towarzyszących reformowaniu edukacji przedszkolnej i wczesnoszkolnej. Obszar ten mógłby zawierać następującą problematykę:

1. Jak nauczyciele oceniają reformę programową edukacji przedszkolnej i wczesnoszkolnej?

2. Jakie pozytywne i negatywne strony reformy potrafią wskazać?

3. Jak oceniają swoje przygotowanie do zmian?

4. Skąd czerpią informacje na temat zmian?

5. Czy czują się pełnoprawnymi uczestnikami zmian?

6. Jakie są opinie nauczycieli na temat przebiegu zmian?

7. Czy dostrzegają konieczność wprowadzenia modyfikacji do założeń reformy programowej?

W jaki sposób należy zmodyfikować te założenia? Które elementy reformy tego wymagają?

Czy potrzebują wsparcia w realizacji zmian?

Jakiej pomocy oczekują nauczyciele: merytorycznej, metodycznej, organizacyjnej?

Przedstawione pytania nie wyczerpuja problematyki poruszonej w artykule. Stanowią jedynie wstępną koncepcję badawczą, która zdaniem autorki, może przyczynić się do wieloaspektowego, krytycznego spojrzenia na obecne zmiany w edukacji. 
MAŁGORZATA KAMIŃSKA-JUCKIEWICZ

\section{Lights and shadows of the curriculum reform in primary and early education - teachers' attitudes}

The article is focused on issues related to teachers' preparation to current educational changes, their needs of knowledge and skills development in connection with dissemination of curriculum reform in preschool and early school education. Based on available documents and journalistic reports, the author presents the current process of changes implementation in educational area.

The article shows findings and conclusions related to teachers' responses to the introduction of the reform gathered during meetings with teachers and puts forward a proposal for research in this field. 